\title{
Moral Turpitude as the Criterion of Offenses that Justify Disbarment
}

Public regulation of the professions to insure high technical efficiency and moral standards is a difficult task. ${ }^{1}$ State control of the disciplinary code of the public profession of the law is complicated because of inherent or inplied disciplinary powers of the courts and the desire of the organized bar for self-government. The allocation of spheres of influence between lay and professional authorities in this regard has had an interesting historical development.

In England, the legal profession arose in the twelfth and thirteenth centuries. One of the early glimpses we have of it is in 1292 when the King, representing the public interest, placed the control of the bar in the hands of the justices. ${ }^{2}$ This delegation of authority was sustained by a long line of statutes in which Parliament confirmed the power in the courts and the courts, by a series of court orders, accepted and exercised it. ${ }^{3}$ The present arrangement indicates a minimum of public control with the burden to maintain professional standards resting primarily on the court and profession. Barristers, subject to visitorial powers of the court and the right to appeal, are governed by the benchers of the Inns of Court. ${ }^{4}$ Solicitors, as officers of the court, come inore

\footnotetext{
I The general question of whether professional standards should be sustained by state regulation or should come froin the profession itself is discussed in (1934) 12 ENCY. Soc. Scr. 476. The argunnent for professional control is well stated in Sunderland, A Unified and Self-Governing Bar (1933) 11 TENN L. Rev. 236; cf. (1935) 33 Mich. L. Rev. 1259.

2 For the early development of the legal profession see 2 HordswortH, HisTORY OF ENGLISH LAW (1922) pp. 311-319, 6 ibid. pp. 431-481. 3 BL. CoMm. *25 ff., mentions solne of the orders governing the profession proceeding from King and Parliament. See also Mattland and Montague, Sketch of English Legal History (1915) p. 97.

3 These statutes and orders are collected in Madgham, Atrornies and Agents (1825) pp. 5-28. For a discussion of these orders and their character acknowledging disciplinary matters to be in the hands of the court, see Lee, The Constitutional Power of the Courts over Admission to the Bar (1899) 13 HaRv. L. REv. 233; Note (1932) 10 N. Y. U. L. Q. REv. 214. The legal profession in England was threatened with drastic public supervision during the period of the Commonwealth. For soine of the popular proposals see 6 HoldswORTH, HISTORY of ENGLISH LAw (1922) pp. 420 ff. Among other suggestions is one that the judges should not sit alone and that "some honest godly man, though no lawyer, have an allowance to sit with them when he will, to see and report the manner and justice of their proceedings to the Lord Protector."

4 For a general discussion of disbarment proceedings in England, see 2 HaIsbury's Laws of England (2d ed. 1931) 357; 2 ibid. 478; Bovey, The Control Exercised by the Inns of Court over Admission to the Bar in England (1913) 38 A. B. A. REP. 767. All power which the Inns of Court have is said to be delegated
} 
immediately under its direction. 5 It is significant that even when Parliament enacts legislation regarding the solicitors it implies that the courts and the Law Society have inherent powers. ${ }^{6}$

to them from the judges. R. v. Benchers of Gray's Inn (K. B. 1780) 1 Doug. 353; $R e$ Justices of the Court of Common Pleas at Antigua (P. C. 1830) 1 Knapp 267. In exercising their powers including that of disbarment, the benchers of the Inn are entirely outside the jurisdiction of the ordinary courts but their decisions are subject to an appeal to the Lord Cbancellor and the Judges of the High Court of Justice sitting as a domestic tribunal. Booreman's Case (1642) 82 Eng. Rep. 464; Cunningham v. Wegg (1787) 29 Eng. Rep. 134. Involuntary disbarment is inflicted by the benchers on a barrister who is guilty of conduct unbecoming his profession. Hudson v. Slade (N. P. 1862) 3 F. \& F. 390. The General Council of the Bar, while it has no disciplinary power, since 1894 has been an advisory body inter alic answering questions and laying down rules regulating the etiquette and practice of the profession as a whole. The distinction between the power of the court and that of the Inns of Court to discipline is in the matter of contempt. The court may discipline a barrister for contempt in respect to acts done in private or professional capacity. The punishment is fine and imprisonment. Anonymous (1741) 2 Atk. 173; Charlton's Case (1836) 40 Eng. Rep. 661; Watt. v. Ligertwood (1874) L. R. 2 Sc. \& Div. App. 361; 3 Mews' Dig. Eng. Case Law (1920) 20; 3 ENG. AND EMr. Dig. (1920) 316. There appear to be no statutes covering barristers. In all other respects the procedure is for the court to report instances of misconduct to the benchers of the Inns of Court.

5 Herbert, The LaW as to Solicitors (1932) p. 10; see the English Solicitors Act, 1932.

Solicitors have been the subject of considerable statutory regulation. The Solicitors Act of 1843, for example, provides the following three statutory grounds for disbarnent: (a) some defect in the articles, service, administration or enrollment of the Solicitor; (b) when he acts for an unqualified person; (c) when lie is guilty of corrupt practice in connection with an election. See 18 Comp. STat. of ENG. 836. THE Solicitors ACT $23 \& 24$ GEo. V. c. 24 (1933) gave further power to the Council of the Law Society; 24 \& 25 GEo. V. c. 45 (1934) took nothing from the power of the courts or the Law Society over the body of Solicitors.

Disciplinary power over solicitors is vested in the court. The grounds for disbarment are both statutory and inherent in the court.

${ }^{6}$ By the Solicitors Act of $1843, \$ 21$, the "Society of Attornies, Solicitors, Proctors and others not being Barristers, practicing in the courts of Law and Equity of the United Kingdom," now called "The Law Society," is invested with administrative authority subject to order by the "Iord chief justice of the Court of Queens Berich, the inaster of the rolls, the lord chief justice of the Common Pleas and the Lord Chief Baron of the Court of Exchequer." The act further in prescribing the three statutory grounds for disbarment infers that the discliplinary measures shall be taken by the court. $51 \& 52$ VICT. c. $65 \$ 12$ (1888) provides that the Masters of the Rolls "shall appoint a committee of not less than three nor more than seven of the members of the Council of the Society" for the purpose of hearing any application to strike a solicitor off the roll. 62 \& 63 VICT. c. 4 s. 1 (1899) gives the Master of the Rolls power to restore a Solicitor who has been struck off the rolls without the customary examination. 9 \& 10 GEo. V. c. 56 (1919) provides procedure for disciplinary proceedings in the hands of the Law Society and directs the Committee of the Socicty to make rules for the hearing of application to disbar.

This entire procedure indicates a legislative intent to give power but to fix responsibility and authority with the Court and the Law Society. The matter of professional discipline remains a matter for the profession and not for the legislature. 
From the background of this comparatively stable adjustment of the problem we turn to the United States. The record is marked by violent swings of the pendulum. At first, in colonial times the bar was the object of such vigorous popular distrust that the public regulation even reached the point of legislation prohibiting lawyers from practicing. ${ }^{7}$ When the services of the learned profession finally were recognized as essential, the courts in general exercised control over the bar as in England. But there were vigorous examples of power vested in the executive and the legislature. ${ }^{8}$ With the adoption of the Federal Constitution promulgating the fundamental principle of the separation of powers, a basis was established for the contention that the judicial department should exercise exclusive control of matters within its jurisdiction. ${ }^{9}$ But the development was otherwise.

Looking at the matter from the professional side, one may feel that the disciplinary broth has been spoiled by the attention of too many cooks in spite of the provisions of state constitutions. ${ }^{10}$ The legislature was the champion of the people agamst executive oppression. ${ }^{11}$ In the early part of the nineteenth century there was hittle opportunity for the judicial department to care for bar disciplime without legislative aid. Popular sentiment decreed a democratic profession with the inevitable lowering of standards. ${ }^{12}$ For many years the only bar association in the

7 WARREN, HISTORY OF THE ATIERICAN BAR (1911) generally; CoNNOR, HISTORY OF NORTf CAROLINA (1919) p. 314. In Pennsylvania the Quaker opposition to the judiciary led to the establishment of arbitration tribunals. Lewis, The Courts of Pennsylvania in the Seventeenth Century (1895) 1 PA. B. A. Rep. 365. See Beard, The Rise of Axrerican Crvinzation (1927) p. 100.

8 In New York, New Jersey and North Carolina the governor assumed power to admit attorneys. Reed, Traming for the Public Professton of the Law (1921) pp. 67-69; Note (1932) 10 N. Y. U. L. Q. Rev. 214, 215; the modern New Jersey procedure is indicated by the cases of $I n$ re Branch (1904) 70 N. J. L. 537, 57 Atl. 431; In re Raisch (1914) 83 N. J. Eq. 82, 90, 90 Atl. 12, 16.

9 For a discussion of the power of the Federal Courts as against Congress in the matter of disbarment, see Waterman, The Federal Bar: A Decentralized System of Admission and Disbarment (1934) 20 A. B. A. J. 762.

10 See Index Drgest of State Constitumons for the provisions of state constitutions regarding the distribution of powers. Courts frequently "imply" a grant of authority over disciplinary matters from the constitutional mandate of separation of powers. See Lee, The Constitutional Power of the Courts over Admission to the Bar (1899) 13 HaRv. L. Rev. 233; see infra notes 18, 19.

11 The courts were set up by the executive branches of the colonial governments and the legislatures had little to do with them. There were some instances, however, of a refusal of a legislature to pay the judges for their services. 4 Osgood, Alterican Colonies IN the 15th Century (1904) pp. 110-113; 2 Osgood, Aaterican Colonies in the 17th Century (1904) p. 285. See Beard, The Rise of Aarerican Civitization (1927) pp. 109-116.

12 From 1800 to 1860 there was a vigorous attack by the public through the legislature upon the monopoly exercised by the legal profession. Its success is indicated by the lowering of standards for admission to the bar. REED, TRAINING for the Public Profession of the Law (1921) pp. 85-102. 
country was the Philadelphia Law Association.13 It was not until the rise of the organized bar in the last quarter of the nineteenth century that sentiment in support of professional as distinguished from public discipline becaine an important issue. ${ }^{14}$ Still more recently the statutes incorporating the bar $^{15}$ bring the situation in the United States into a position more nearly comparable to that enjoyed by the solicitors in England. Judicial comment upon those statutes indicates a synpathetic approval but declines to interpret thein as a delegation of judicial powers by the legislature to the bar. ${ }^{16}$

This in brief is the historical background in this country of the question of state versus professional control over the bar. The end is not yet. The public press gives indications of proposals to limit the judicial power in general. ${ }^{17}$ The legal status of the matter may be suminarized as follows: Some courts have definitely repudiated legislative attempts as unconstitutional; ${ }^{18}$ in other cases the court has admitted controlling power in the legislature; but in the majority of cases

. 13 Wickser, Bar Associations (1930) 15 CoRs. L. Q. 390, 394. See also "The Law Association of Philadelphia," addresses delivered March 13, 1902, and papers prepared or republished to commemorate the centennial celebration of the Law Association of Philadelphia, Pennsylvania.

14 Webber, Origin and Use of Bar Association (1921) 7 A. B. A. J. 297; Proctor, Practical Utility of Bar Associations (1899) 59 Alb. L. J. 373.

15 Ara. Code. Ann. (1928) \$§6220-6239; Ariz. Session Laws 1933, c. 66; CaL. Gen. Laws Act. 591; Idaho Code Ann. (1932) §\$ 3-401 to 3-417; Ky. Rev. Stat. (Baldwin, Supp. 1934) \$101-1; La. Acts 2d Ext. Sess. 1934, No. 10, p. 70; MIcr. Comp. Laws (Mason, Supp. 1935) \$13603-1; Miss. Gen. Laws 1932, c. 121; Nev. CoMp. Laws (Hillyer, 1929) §§ 540-590; N. M. CoMp. STat. (1929) §§ 9-201 to $9-212$; N. C. Code (Michie, Supp. 1933) $\S \S 215$ (1) to 215 (18); N. D. CoMp. Laws (Supp. 1925) §§813a1-813a5; Okla. Laws 1929, c. 264; Ore. Laws 1935, c. 28 ; S. D. Laws 1931, c. 84 ; UTAH Rev. Stat. (1933) \$§6-0-1 to 6-0-23; Wase. Rev. Stat. (Remington, Supp. 1934) $\$ \S 138-1$ to $138-17$.

16 Brydonjack v. State Bar (1929) 208 Cal. 439, 281 Pac. 1018; Carpenter v. State Bar (1931) 211 Cal. 358, 295 Pac. 23; In re Edwards (1928) 45 Idaho 676, 266 Pac. 665; In re Barclay (1933) 82 Utah 288, 24 P. (2d) 302. For a collection of State Bar Acts and cases construing them see State Bar Acts ANnotated (rev. ed. 1934).

it The public press is full of suggestions to limit the power of. the Supreme Court of the United States or to expand the constitution. N. Y. Times, Jan. 21, 1934, No. 2, at 1; N. Y. Times, Jan. 25, 1935, at 22; N. Y. Times, Jan. 26, 1935, at 16.

18 In re Edwards (1928) 45 Idaho 676, 266 Pac. 665; In re Royall (1928) 33 N. M. 386, 268 Pac. 570; In re Cannon (1932) 206 Wis. 374, 240 N. W. 441. Other cases indicate that the legislature cannot limit or take away the "inherent" power of the court. In re Lavine (1935) 2 Cal. (2d) 324, 41 P. (2d) 161; In re Bailey (1926) 30 Ariz. 407, 248 Pac. 29; In re Spriggs (1930) 36 Ariz. 262, 284 Pac. 521; In re Day (1899) 181 ㄲl. 73, 53 N.E. 646; In re Opinion of the Justices (1932) 279 Mass. 607, 180 N. E. 725 ; In re Humphrey (1929) 178 Minn. 331, 227 N. W. 179; In re Richards (1933) $333 \mathrm{Mo}$. 907, $63 \mathrm{~S}$. W. (2d) 672; In re Branch (1904) 70 N. J.L. 537, 57 Atl. 431; In re Bruen (1918) 102 Wash. 472, 172 Pac. 1152. 
it has been held that a sort of coördinate authority exists. ${ }^{19}$ This coauthority operates either as a matter of comity to a sister branch of the government or as a recognition by the court that both departments should function in the field because it is not clear that either has exclusive control. ${ }^{20}$

Confusion results from this: (1) because there are divergent authorities dictating the grounds for discipline: (a) statutes specifying offenses; (b) court decisions interpreting the terms of a general statute; (c) court decisions based upon the power of the court implied from the constitution and distinct from statute; (2) because the fundamental standards of conduct produced by this administrative machinery are an ill-digested mixture conceived by lay and professional minds. The legislature representing the public may lay down rules for discipline of attorneys appropriate to control the actions of a private citizen or may require the profession to conform to that sort of conduct which the layman thinks is proper for a lawyer. The courts and the bar view the matter as a professional task in which the layman, because of his unfamiliarity, has little justification or opportumity for forming a reasoned opinion; and which he should, therefore, leave to those who are better fitted by experience and interest. Confusion in the disbarment field, then, exists not only because there are two overlapping promulgating agencies but because the fundamental standards of conduct differ. We find lay standards of right and wrong; the lay idea of what professional standards ought to be and the professional man's evaluation of his own conduct. An excellent example of this confusion is the statutory use of the term "moral turpitude" to distinguish acts for which disbarment should be the penalty.

LEGISLATIVE CONTROL OF BAR DISCIPIINE

The legislatures in the United States have gone further than Parliament in controlling bar discipline. The acts may be divided into:

A. Those similar to the English Solicitors Acts which hand the matter over to the organized bar. These provisions, as interpreted by

19 Courts have accepted a condition of cooperation in the following cases: Ex parte Secombe (1856) 19 How. (60 U.S.) 9; Ex parte Garland (1866) 4 Wall. (71 U. S.) 333,379 ; Ex parte Yale (1864) 24 Cal. 241; In re Chapelle (1925) 71 Cal. App. 129, 234 Pac. 906; Ex parte Coleman (1891) 54 Ark. 235, 15 S. W. 470; In re Taylor (1877) $48 \mathrm{Md}$. 28; In re Opinion of the Justices (1932) 279 Mass. 607,180 N. E. 725 ; State v. Johnson (1916) 171 N. C. 799, 88 S. E. 437 ; In re Olmsted (1928) 292. Pa. 96, 140 Atl. 634; State Board v. Phelan (1931) 43 Wyo. 481,5 P. (2d) 263; see also cases cited supra note 16.

20 Reed, AnNual Review of Legal Education (1930) p. 5; Cheadle, Inherent Power of the Judiciary over Admittance to the Bar (1932) 7 Wase. L. REv. 320; Green, The Court's Power over Admission and Disbarment (1925) 4 Tex. L. Rev. 1, 17; Lee, Constitutional Power of the Courts over Admission to the Bar (1889) 13 HARv. L. REv. 233, 251. 
the courts, in so far as they amount to a cession of the field to the Bar, avoid the difficulty discussed in this paper. ${ }^{21}$

B. Those where the legislature has prescribed a set of standards, violation of any of which calls for disciplinary action. These statutes nay be divided as follows:

1. A listing of specific offenses..22 As to them the court has no discretion.

2. A "catch-all" phrase covering acts "involving moral turpitude." ${ }^{23}$ It is used, perhaps, with some brave desire to trip that oldtime professional villam now called "the lawyer-criminal."

3. A "catch-all" phrase covering acts involving "professional misconduct." ${ }^{24}$ It is used, perhaps, with the thought of defining the activities of the "shyster."

21 See Sunderland, A Unified and Self-Governing Bar (1933) 11 TENN. L. REv. 236.

${ }^{22}$ The following specific offenses are of most frequent occurrence: improperly retaining client's money, violation of court order, soliciting professional business, and conviction of felony. CAL. Code Crv. Proc. \$287; ALA. Code (Michie, 1928) $\$ \S 6256,6257$; ARIz. Code (Struckmeyer, 1928) \$201; ARK. Dig. STAT. (Crawford \& Moses, 1921) \$610; D. C. Code (1929) tit. 18, §53; Fla. Comp. Laws (1927) \$4172; GA. Code. (1933) \$9-501; IdAHo Code ANN. (1932) \$3-301; IIL. Rev. STat. (Smith-Hurd, 1933) c. 13, \$7; IND. STat. ANN. (Baldwin, 1934) \$836; Iowa Code (1931) \$10930; Kan. Rev. Stat. ANN. (1923) c. 7, \$111; Mo. ANN. Code (Bagby, Supp. 1929) art. 10, §10e; Mass. Laws AnN. (Michie, 1933) c. 221, \$40; Mich. Comp. Laws (1929) \$§ 13,585, 13,594; Minn. Stat. (Mason, 1927) §5697; Miss. Code ANn. (1930) §§ 3695, 3703; Mo. Rev. Stat. (1919) \$681; Mont. Rev. Codes (Choate, 1921) \$8961; Nebr. Comp. Stat. (1929) \$7-106; Nev. Comp. Laws (Hillyer, 1929) \$\$ 604, 616; N. M. Star. Ann. (Courtright, 1929) § 9-135; N. Y. CosrP. Laws (Cahill, 1930) c. 31, \$§ 88, 477; N. D. Comp. Laws ANN. (1913) \$800; OKIA. Comp. Stat. ANn. (1921) \$4106; Orz. Code (1930) §32-502; PA. Stat. (West, 1920) § 864; S. C. Code (Michie, 1932) \$323; S. D. Conpr. Laws (1929) \$5271; Tenv. Code (1932) \$9974; Utal Rev. Stat. Ann. (1933) §6-0-36; VA. Code ANN. (Michie, 1930) § 3423; Wash. Rev. Stat. ANn. (Remington, 1932) \$139-14; WIS. Stat. (1933) \$256.29; WYo. Rev. STAT. ANN. (1931) §9-114.

23 The following statutes mclude either "felony or misdemeanor involving moral turpitude," "misdemeanor involving moral turpitude," or "offense involving moral turpitude." Car. Code Crv. Proc. \$287; Ala. Code (Michie, 1928) \$6256; Ariz. Code (Struckmeyer, 1928) § 201; D. C. Code (1929) tit. 18, § 54; GA. CodE (1933) \$9-501; Idaeto Code ANN. (1932) \$3-301; Ind. Stat. ANN. (Baldwin, 1934) §836; IowA Code (1931) §10930; MD. ANN. Code (Bagby, Supp. 1929) art. 10, §10e; MrnN. Stat. (Mason, 1927) §5697; Mo. Rev. Stat. (1929) §681; Mont. Rev. Codes (Choate, 1921) \$8961; Nev. CoMp. Laws (Hillyer, 1929) §604; N. M. Stat. Ann. (Courtright, 1929) §9-135; N. D. Comp. Laws ANN. (1913) § 800; OFino ANN. Code (Tbrockmorton, 19.30) \& 1707; OkLA. Comp. Stat. Ann. (Bunn, 1921) § 4106; ORE. Code ANN. (1930) \$32-502; S. D. Concp. Laws (1929) \$5271; Tenn. Code (1932) \$9974; Utae Rev. Stat. ANN. (1933) §6-0-36; Wase. Rev. Stat. ANN. (Remington, 1932) \$139-14; W. VA. Code (Michie, 1932) \$2855; Wyo. Rev. Stat. ANN. (1931) \$9-114. In the other states the term does not appear as a basis for disbarment.

24 The words "unprofessional conduct" or their equivalent appear in the following: ARIz. Code (Struckmeyer, 1928) \$201; ARK. Dig. STAT. (Crawford \& 
The lawyer "cad," whose activities in private, as distinguished from professional life, bring discredit upon the profession, seems not to have appeared on the legislative screen.

Had the legislature stopped short at this point, the courts might have crystallized the concept of "moral turpitude" with a reasonable degree of certainty. The matter is complicated, however, by the statutory use of the same tern to cover moral dereliction in other cases: exclusion of aliens ${ }^{25}$ and deportation; ${ }^{26}$ competency of witnesses; ${ }^{27}$ slander and defamation proceedings; ${ }^{28}$ revocation of a physician's license; ${ }^{29}$ application of an habitual offenders act. ${ }^{30}$

The exact definition of the term is not difficult. The one most favored by the courts is found in Bouvier's Law Dictionary: "An act of baseness, vileness or depravity in the private and social duties which a man owes to his fellow men or to society in general, contrary to the accepted and customary rules of right and duty between man and man." 31

But the problem does not lie with the definition. That is clear. The question which has troubled the courts is how to determine the stan-

Moses, 1921) §610; Coro. AnN. Stat. (Mills, 1930) § 290; Del. Rev. Code (1915) c. 112 , § 10; D. C. Code (1929) tit. 18, § 53; Fua. Comp. Laws (1929) § 4172; Irr. Rev. Stat. (Smith-Hurd, 1933) c. 13, \& 6; LA. GeN. Star. (Dart, 1932) \$464; Mo. ANn. Code (Bagby, Supp. 1929) art. 10, \$10e; Nev. Comp. Laws (Hiilyer, 1929) \$604; N. Y. Conm. LAws (Cahill, 1930) c. 31, §88; N. C. CodE ANN. (Michie, Supp. 1933) § 215 (11); OHIo ANN. Code (Throckmorton, 1930) § 1707; Tenn. Code (1932) § 9974; Texas Rev. Civ. Stat. (Vemon, 1928) art. 313; VA. Code AnN. (Michie, 1930) §3423; Wast. Rev. Star. ANN. (Remington, 1932) \$139-14.

2539 Stat. (1917) 875, 8 U. S. C. A. (1927) \$136 (e) ; U. S. v. Uhl (C. C. A 2d, 1914) 210 Fed. 860 (conviction of criminal libel does not involve moral turpitude).

2639 StaT. (1917) 889, 8 U. S. C. A. (1927) \$155; U. S. v. Day (S. D. N. Y. 1926) 15 F. (2d) 391 (assault involves moral turpitude); Bendel v. Nagle (C. C. A. 9th, 1927) $17 \mathrm{~F}$. (2d) 719 (rape involves moral turpitude).

27 Ala. AnN. Code (Michie, 1928) § 7722; VT. Gen. Laws (1917) § 1897.

28 AlA. ANN. Code (Michie, 1928) \$4923.

29 Ala. Ann. Code (Michie, 1928) \$2847; Ark. Dig. Stat. (Crawford \& Moses, 1921) §8242; Colọ. Conip. Laws (1921) \$4536; Ga. Code (1933) \$84-916; Iowa Code (1931) §2492; MInN. Stat. (Mason, 1927) §5707; N. D. CoMp. Laws ANN. (1913) \& 468 .

30 N. D. Laws 1927 , c. 126 ; State v. Malusky (1930) 59 N. D. 501, 230 N. W. 735 .

31 Ex parte Machida (W.D. Wash. 1921) 277 Fed. 239; In re Bartios (D. Neb. 1926) 13 F. (2d) 138; In re Coffey (1899) 123 Cal. 522, 56 Pac. 448; Moore v. State (1915) 12 Ala. App. 243, 67 So. 789; Blackburn v. Clark (1897) 19 Ky. L. 649, 41 S. W. 430; Lee v. Stanfill (1916) $171 \mathrm{Ky} .71,186$ S. W. 1196; Baxter v. Mohr (1902) 37 Misc. Rep. 833, 76 N. Y. Supp. 982; State v. Mason (1896) 29 Ore. 18, 43 Pac. 651. For other definitions see Coykendall v. Skrmetta (C. C. A. 5th, 1927) 22 F. (2d) 120; Fort v. City of Brinkley (1908) 87 Ark. 400, 112 S. W. 10S4; In re Henry (1909) 15 Idaho 755, 99 Pac. 1054; OxroRd ENg. Dict., WEBSTER DICT. 
dard of right conduct as applied to a given set of facts. By what significant criteria may one recognize the requisite quality of baseness implicit in the acts of one's fellows? The relative character of the words "baseness," "vileness," "depravity" makes an absolute definition of little value. The confusion in meaning can be discovered more effectively by studying examples of the application of these terms to specific fact situations.

EFFORTS OF THE COURTS TO DETERMINE THE MIEANING OF THE PHRASE MORAL TURPITUDE

Court decisions applying the term "moral turpitude" to the facts of specific cases fall under three categories:

A. There are certain acts in general accepted as involving moral turpitude. ${ }^{32}$ Among these are found nuurder, larceny, the offenses included at common law under the terms "crimen falsi" and "infamous crimes" (but the term is broader than and not synonymous with either of these).

B. There are certain acts, in general, accepted as not involving moral turpitude. ${ }^{33}$ Among these are simple assault and battery and violation of mimor police regulations.

32 (1) MURDER: Matter of Patrick (1910) I36 App. Div. 450, 120 N. Y. Supp. 1006 (attorney disbarred). (2) LARCENY: Tillinghast v. Edmead (C. C. A. 1st, 1929) 31 F. (2d) 81 (alien deported); In re Henry (1909) 15 Idaho 755, 99 Pac. 1054 (attorney disbarred); People v. Schintz (1899) 181 IIl. 574, 54 N. E. 1011 (same); Ex parte Thompson (1898) 32 Ore. 499, 52 Pac. 570 (same); Pendergraft v. State (1927) 107 Tex. Cr. 326, 296 S. W. 885 (witness impeached) ; Redway v. Gray (1858) 31 Vt. 292 (slander); In re Liliopoulos (1933) 175 Wash. 338, 27 P. (2d) 691 (attorney disbarred). Contra: Blackburn v. Clark (1897) $19 \mathrm{Ky}$. L. 649, 41 S. W. 430 (slander). (3) EMBEzzLEMENT: In re Cruickshank (1920) 47 Cal. App. 496, 190 Pac. 1038( attorney disbarred); People v. Bryce (1906) 36 Colo. 125, 84 Pac. 816 (same); People v. George (1900) 186 Ill. 122, 57 N. E. 804 (same); In re Rockmore (1910) 139 App. Div. 71, 123 N. Y. Supp. 928 (same); In re Turner (1918) 104 Wash. 276, 176 Pac. 332 (attorney suspended). (4) Forgery: People v. Walkey (1899) 26 Colo. 483, 58 Pac. 591 (attorney disbarred); Nelson v. Commonwealth (1908) $128 \mathrm{Ky} .779,109$ S. W. 337 (same); State v. Stringfellow (1911) 128 La. 463, 54 So. 943 (same); In re Sutton (1914) 50 Mont. 88, 145 Pac. 6 (same). (5) PERJuRy: It re Ulmer (N. D. Ohio, 1913) 208 Fed. 461 (attorney disbarred); Kaneda v. U. S. (C. C. A. 9th, 1922) 278 Fed. 694 (alien excluded); In re O'Keefe (1918) 55 Mont. 200, 175 Pac. 593 (attorney disbarred) ; In re Klatzkie (1911) 142 App. Div. 352, 126 N. X. Supp. 842 (same). (6) BRIBERY: In re Wellcome (1899) 23 Mont. 450, 59 Pac. 445 (attorney disbarred); In re Boland (1908) 127 App. Div. 746, 111 N. Y. Supp. 932 (same) ; In re Simpson (1920) 79 Okla. 305, 192 Pac. 1097 (same); (7) BLackmarl: People v. Varnum (1901) 28 Colo. 349, 64 Pac. 202 (attorney disbarred) ; In re Hart (1901) 116 N.Y. Supp. 193 (same). (8) Making False Reports to Public Offichars: U.S. ex rel. Medich v. Burmaster (C. C. A. 8th, 1928) 24 F. (2d) 57 (alien deported); In re Diesen (1928) 173 Minn. 297, 217 N. W. 356 (attorney disbarred); In re Peters (1925) 73 Mont. 284, 235 Pac. 772 (same); In re Wiltsie (1920) 109 Wash. 261, 186 Pac. 848 (same).

33 U. S. ex rel. Mongiovi v. Karnuth (W. D. N. Y. 1929) 30 F. (2d) 825 ; Gillman v. State (1910) 165 Ala. 135, 51 So. 722; Edenfield v. State (1914) 14 Ga. App. 401, 81 S. E. 253; Holmes v. State (1912) 68 Tex. Cr. 17, 150 S. W. 926. 
C. There is an area of conflict. ${ }^{34}$ In it are found such acts as sex offenses, violation of the National Prohibition Act and related legislation. It is because the courts cannot agree that the question arises as to the usefulness of the phrase as a practical test.

As an example of this conflict it is desirable to compare two cases somewhat similar as to the facts. Both were violations of the national liquor laws. In both cases the offender was an official. In the Rudolph case $^{35}$ where a.retired policeman was convicted of the "unlawful possession and transportation of intoxicating liquors" the court held that the offense did involve moral turpitude. "There is no hard and fast rule as to what constitutes moral turpitude. It cannot be measured by the nature or character of the offense, unless, of course, it be an offense, imherently criminal, the very commission of which implies a base and depraved nature. The circumstances attendant upon the commission of the offense usually furnish the best guide. For example, an assault and battery may mvolve moral turpitude on the part of the assailant in one case and not in another. Intent, malice, knowledge of the gravity of the offense, and the provocation, are all elements to be considered."

In the Bartos case, ${ }^{36}$ where an attorney manufactured and possessed in his home for use by himself and his guests seven hundred quarts of beer, the court held that the act did not involve moral turpitude, saying: "This (moral turpitude) is an old phrase in the law, and its

34 Whether or not assault involves moral turpitude depends on the circumstances. United States v. Day (S.D.N.Y.1926) 15 F. (2d) 391 (alien deported). Cf. Ciaunbelli v. Johnson (D. Mass. 1926) 12 F. (2d) 465. Sexual offenses present a more difficult problein. Adultery involves inoral turpitude. Ex parte Rodriguez (S. D. Tex. 1926) 15 F. (2d) 878; Grievance Committee v. Broder (1930) 112 Conn. 269, 152 Atl. 292; Morrison v. State (1919) 85 Tex. Cr. 20, 209 S. W. 742. Apparently fornication does not involve moral turpitude. Ex parte Isojoki (N. D. Cal. 1915) 222 Fed. 151; Ex parte Rocha (S. D. Tex. 1929) 30 F. (2d) 823. Bigamy has been held to involve moral turpitude. United States v. Williams (C. C. A. 2nd, 1912) 200 Fed. 538; United States v. Brooks (E. D. Mich. 1922) 284 Fed. 908; Cf. Wong Yow v. Weedin (C. C. A. 9th, 1929) 33 F. (2d) 377.

Violations of liquor laws have resulted in the sbarpest conflict. The following cases have held such acts to involve moral turpitude: Rudolph v. U. S. (Ct. of App. D. C., 1925) 6 F. (2d) 487; Riley v. Howes (D. Me. 1927) 17 F. (2d) 647; Kurtz v. Farrington (1926) 104 Conn. 257, 132 Atl. 540; State v. Bieber (1926) 121 Kan. 536, 247 Pac. 875; Underwood v. Commonwealth (1907) 32 Ky. L. 32, 105 S. W. 151; State v. Malusky (1930) 59 N. D. 501, 230 N. W. 735; Hendrix v. State (1911) 4 Okla. Cr. 611, 113 Pac. 244; State v. Edmunson (1922) 103 Ore. 243, 204 Pac. 619; In re Finch (1930) 156 Wash. 609, 287 Pac. 677. Contra: Bartos v. U. S. District Court (C. C. A. 8th, 1927) 19 F. (2d) 722; Coykendall v. Skrmetta (C. C. A. 5th, 1927) 22 F. (2d) 120; Baugli v. State (1927) 215 Ala. 619, 112 So. 157; Fort v. City of Brinkley (1908) 87 Ark. 400, 112 S. W. 1084 ; Jennings v. State (1918) 82 Tex. Cr. 504, 200 S. W. 169; McGovern v. Smith (1902) 75 Vt. 104, 53 Atl. 326.

35 Rudolph v. U. S. (Ct. of App. D. C. 1925) 6 F. (2d) 487, 488.

${ }^{36}$ Bartos v. U. S. District Court (C C. A. 8th, 1927) 19 F. (2d) 722, 724. 
meaning is demonstrated in cases in which a prior conviction is attempted to be proven for the purpose of impeaching a witness. It is subjective in meaning and restricted to those who commit the gravest offenses-felonies, infamous crimes, those that are malum in se. They disclose the inherent character, that he is of depraved mind, and because thereof he is not worthy of belief even under oath ... A thief is a debased unan, he has no moral character. The fact that a statute may classify his acts as grand or petit larceny, and not punish the latter with imprisonment, and declare it to be only a misdemeanor, does not destroy the fact that theft, whether it be grand or petit larceny, involves moral turpitude. It is malum in se, and so the consensus of opimion-statute or no statute-deduces from the commission of crimes inalum in se the conclusion that the perpetrator is depraved in mind and is without moral character, because, forsooth, his very act involves moral turpitude ..."

Answering the contention that moral turpitude has no definite meaning and fluctuates, the opinion continues: "This is doubtless so when viewed solely as a question of morals and long periods of time are taken into consideration. But when private rights are being adjudicated they are determined by rules of the civil law, not the moral; and so the civil law fixes a definite meaning to the phrase. It says the commission of crimes malum in se, infamous offenses and those classed as felonies involve noral turpitude,-none others. The phrase is centuries old, it has a definite meaning."

Quite aside from the merits of the respective decisions on the facts, the language of the courts reveals a wide divergence as to the concept underlying the words "noral turpitude." To the court in the Rudolph case the tern is a vague one, allowing discretion in application. To the court in the Bartos case the term has a fixed, absolute meaning.

There is no need to discuss the relative merits of discretionary and fixed terms. The courts in disbarment proceedings need a "catch all" phrase sufficiently flexible to enable them to keep the administration of justice free from men who are clever enough to evade rigid provisions. It is also helpful to have certain rigid standards. But if the term "moral turpitude" is held to have a rigid meaning, some flexible term is needed to supplement it.

It is submitted that a perusal of the authorities will lead to the conclusion that the approach of the Rudolph case is nore realistic than that of the Bartos case. 
THE TERM MORAL TURPITUDE AS INTERPRETED BY THE COURT

HAS, ACCORDING TO THE WEIGHT OF AUTHORITY, A

VAGUE, NEBULOUS, DISCRETIONARY MEANING

The concept behind the phrase "moral turpitude" involves factors as to which there is agreement as well as another area of conflict. The elements of intent and knowledge are regarded even in the Bartos case as important. ${ }^{37}$ But beyond this the road forks.

Those who hold that the meaning is definite contend that it is identical with or at least similar to certain other classifications used in the criminal law and that the well recognized significance of these other terms clarifies the instant standard. Typical of these arguments are the following:

A. The legislature is the ultimate modern device for expressing the cominon conscience of the people. When any statute is passed creating a criminal offense, it is ipso facto impliedly branded with baseness. A violator of the act is guilty of a crime involving moral turpitude and must suffer the consequences. This entirely logical and simple reasoning appears to lie at the basis of several decisions. ${ }^{38}$ Unfortunately for its acceptance the words of the statutes providing for bar discipline are clearly open to another interpretation-that the phrase is used to distingnish more serious from less serious offenses. ${ }^{39} \mathrm{~A}$ line must therefore be drawn somewhere.

B. The legislature has left it to the courts to draw such an administrative line. The courts in so doing should not rely on individual inspiration but should strive to apply well recognized principles.

37 There seems to be no particular objection to the proposition that the mental element is an important one in determining the presence of moral turpitude. If the wrong is unintentional or if the act is made improper by statute without regard to the mental element, it is not moral turpitude. Pullman Car Co.v. Central Trans. Co. (C.C.E.D.Pa. 1894) 65 Fed. 158. Similarly, if the mental element is negligence moral turpitude is not involved. "Even in the case of wilful acts, conventional ideas of morality often seem to be largely imdependent of the harmfulness of the act, and to be based rather on a traditional or intuitive belief that certain acts indicate a depraved state of mind." Note (1926) 5 NEB. L. BuLL. 216,217 . Again the standard of conduct is not to be puritanical. In re Hopkins (1909) 54 Wash. 569, 103 Pac. 805, 806.

38 Rudolph v. U. S. (Ct. of App. D. C. 1925) 6 F. (2d) 487; Riley v. Howes (D. Me. 1927) 17 F. (2d) 647; State v. Bieber (1926) 121 Kan. 536, 247 Pac. 875; Hendrix v. State (1911) 4 Okla. Cr. 611, 113 Pac. 244; State v. Edmunson (1922) 103 Ore. 243, 204 Pac. 619.

39 U. S. v. Day (C. C. A. 2d, 1929) 34 F. (2d) 920; Coykendall v. Skrmetta (C. C. A. 5th, 1927) 22 F. (2d) 120 ; Bartos v. U. S. District Court (C. C. A. Sth, 1927) 19 F. (2d) 722; Baugh v. State (1927) 215 Ala. 619, 112 So. 157; Fort v. City of Brinkley (1908) 87 Ark. 400, 112 S. W. 1084; State Board v. Friedman (1924) 150 Tenn. 152, 263 S. W. 75; Jennings v. State (1918) 82 Tex. Cr. 504, 200 S. W. 169. 
Obviously the legislature was thinking in terms of the two common distinctions in criminal law:

1. Moral turpitude is a test similar in meaning to that dividing felonies from misdemeanors. ${ }^{40}$ Unfortunately for this line of reasoning it is not generally adopted. Felonies and misdemeanors, today largely statutory, are divided on the basis of the punishment and not the nature of the act.

2. Moral turpitude is a test similar in meaning to that dividing acts "mala in se" from those "mala prohibita." The authorities do not bear out this distinction. ${ }^{41 a}$ Nor is the distinction itself precise enough to help in the solution of disbarment problems.

Unless, as a matter of law, every criminal act involves "moral turpitude," every judicial application of the phrase to the facts of a specific case mvolves the exercise of some judicial discretion. If that discretion could be exercised with the aid of an accepted and precise distinction, if "moral turpitude" were synonymous with felonies or acts mala in se, and if the distimctions represented by those phrases were applicable to modern disbarment proceedings, it would be possible to decide in favor of a strict construction of the legislative language. But these conditions are not met and one is driven to the conclusion that the former term does not have a fixed meaning.

To demonstrate the unsatisfactory character of the argument advanced by the supporters of a fixed meaning does not by any means admit the correctness of the opposing claim. The courts which have held "moral turpitude" to be vague, flexible and discretionary in mean-

40 Bartos v. U. S. District Court (C. C. A. 8th, 1927) 19 F. (2d) 722. The assumption that some felonies do not involve moral turpitude and that some misdemeanors do, is implicit in the disbarment statutes using the phrase. Otherwise "felony or misdemeanor involving moral turpitude" would be surplusage.

41. It is probably true that all crimen falsi involve moral turpitude and that "infamous crimes" are equally serious in their nature. But the offenses involving moral turpitude are of wider application. The term malum in se has been held to be indicative of crimes involving moral turpitude. Bartos v. U. S. District Court, supra note 40; Tillinghast v. Edmead (C. C. A. 1st, 1929) $31 \mathrm{~F}$. (2d) 81 ; Ex parte Marshall (1922) 207 Ala. 566, 93 So. 471; Fort v. City of Brinkley (1908) 87 Ark. 400, 112 S. W. 1084. Cf. Note (1927) 75 U. of PA. L. Rev.. 357, 358. But see U. S. v. McCandless (E. D. Pa. 1928) 28 F. (2d) 287; In re Finch (1930) 156 Wash. 609, 287 Pac. 677.

4la At common law a felony was distinguished from a misdemeanor by forfeiture of property and capital or other punishment. Today felonies are statutory. See Mrller, Handook of Crmintai Law (1934) pp. 23 ff. The label "felony" does not necessarily describe an act involving moral turpitude. U. S. v. McCandless, supra note 41; Jones v. Brinkley (1917) 174 N. C. 23, 93 S. E. 372; State Board v. Friedman (1924) 150 Tenn. 152, 263 S. W. 75. See Notes (1929) 43 HARv. L. REv. 117; (1930) 6 WIs. L. REv. 40. Even more persuasive are the cases which hold certain felonies do not involve moral turpitude. Baugh v. State (1927) 215 Ala. 619, 112 So. 157. See supra notes 33 and 34 . 
ing have not found a way to interpret it adequately for disbarment purposes. Granting the need for flexibility, and a consideration of all the circumstances of the case, ${ }^{42}$ the procedure is subject to the criticism that a judge may unconsciously mistake his own bias for an intuitive perception of the common conscience. ${ }^{43}$ A judge applying the test of "moral turpitude" is not merely expounding a principle of law. $\mathrm{He}$ is setting a moral standard, legislating perhaps, interpreting the public mind. Unless the legislature has supplied a precise definition the judge of necessity makes an exploratory excursion into the field of morals. This is not primarily a judicial function and the results all too often are in confiict.

The discussion between the adherents of the strict versus those supporting a flexible construction of the tern assumes the presence of something spoken of as the common conscience or the moral standard of the community. The disagreement is as to the ineans of ascertaining. the moral judgment of the community respecting a particular act. Shall the legislature or the court be the agency to formulate, determine and promulgate the principle? If the discussion is limited to this matter the legislature has the advantage. It is more closely in touch with public sentiment and opimion. Its methods of arriving at a basis for legislation defining degrees of morality does not include the cumbersome taking of expert testimony, the deternination of those qualified as expert witnesses on the subject, nor the judicial balancing of arguments pro and con in matters where the public is not in a state of agreement. The judicial process whether it proceeds on a basis of individual intuition or through the customary channels of hitigation is not adapted to the task of making effective surveys of the instant status of moral codes.

If the legislature is recognized as the inore efficient expounder of the coinmon conscience the remedy is to attach to each criminal offense a legislative label indicating the appropriate ineasure of baseness and depravity. Several writers have already made this suggestion. ${ }^{44}$ But such a solution delivers into the hands of the legislature exclusive control of a large part of the field of activities of lawyers. If progress is to be

42 See Note (1927) 75 U. of PA. L. Rev. 357, 358.

43 At one time the code of morals was in tangible form, consisting of the Bible, the Canon and Civil law, and Aristotle. See 2 HoldswortH, History of ENGLISH LAw (1922) 128 for a discussion of the intellectual, political and legal ideas of the middle ages. This code had for its enforcement a definite system of courts. For the jurisdiction of the Ecclesiastical Court, see CARTER, HIsTORY OF THE Enclise Couris (5th ed. 1927) p. 146. In the latter part of the 19th Century ethical thought was influenced by Darwinian theories. The idea of evolutionary ethics conflicted with that of the middle ages based on authority. See (1933) 10 ENcyc. Soc. ScI. 643-649.

44 See Note (1929) 43 Harv. L. Rev. 117; Note (1931) 17 Iowa L. Rev. 76. 
along the line of professional discipline, it would be a step backward to adopt the suggestion.

There is still another way out of the dilemma. The problem of professional discipline does not revolve fundamentally around the dispute of strict versus flexible construction of the term "moral turpitude." Since neither the court nor the legislature is a perfect medium for the exposition of the state of public morals as a test for professional misconduct, one may question whether the common conscience, even if obtained, is the desired factor. Granting that lay standards of conduct may be important in the field of criminal law, deportation of aliens, defamation and similar cases, it by no means follows that they are applicable to the specialized problems of a professional group. ${ }^{45}$ Lawyers are necessarily held to a higher or at least to a more specialized standard of conduct than laymen. ${ }^{46}$ To discipline them professionally by lay standards does not encourage the growth of higher modes of professional conduct.

\section{THE THEORY OF A PROPOSED SOLUTTON}

It is submitted that the ideal solution of problems of professional discipline is not so simple as to accept either the legislature or the court as the propliet to which is revealed the state of morals of the people or the common conscience. The courts have held repeatedly that a disbarment proceeding is not a criminal matter. ${ }^{47}$ It is undertaken not for punishment but for the purification of the profession. ${ }^{48}$ When evolutionary ethics with its doctrmes of determmism began to compete in the public mind with the entrenched formulae of a free-will pliilosoply, the atmosplere in which "moral turpitude" flourished was materially affected. A modern remedy then would seem to be in the direction of an abandonment of the old concepts and administrative

45 Though it may be true, generally speaking, that the purpose of both the criminal law and disbarment proceedings is to prevent injury to the public, still the criterion for the former is ill-adapted to professional ethics. The lawyer, as an individual, must conform to the lay standard of morals; but as a professional man he is required to conform to the ethics of his profession. That "professional ethics" connotes something different than "general ethics" is evident.

46 In re Schachne (D. N. Y. 1934) 5 F. Supp. 680; In re H- S- (Mo. App. 1934) 69 S. W. (2d) 325; People ex rel. Karlin v. Culkin (1928) 248 N. Y. 465, 162 N. E. 487 . See Note (1929) 3 So. CarTF. L. Rev. 46, 51.

47 Ex parte Thoinpson (1933) 228 Ala. 113, 152 So. 229; In re Keenan (Mass. 1934) 192 N. E. 65 ; In re H- S-, supra note 46 ; State ex rel. Seton v. Arnold (1934) 145 Ore. 634, 28 P. (2d) 836.

48 ". . . the disbarment of attorneys is not intended for the punishment of the individual but for the protection of the courts and the legal profession." In re Vaughan (1922) $189 \mathrm{Cal}$. 491, 496, 209 Pac. 353, 355. "The purpose of such proceedings is to protect the public and those charged with the administration of justice from the misconduct of persons ... unfit to perform the important duties which devolve upon an attorney at law." In re Wourms (1918) 31 Idaho 291, 293, 170 Pac. 919, 920. 
machinery and the adoption of new ones. The solution is rendered all the easier of accomplishment because many of the states ${ }^{49}$ do not have statutes prescribing moral turpitude as a test in disbarment proceedings.

In substituting a new test for professional discipline it is desirable to avoid both the procrustean practices of the rigid formula and the protean discretions of the circumstances of the case. These may be necessary incidents in interpreting a standard of lay conduct. The profession requires for its guidance a definite but flexible set of morals and standards of etiquette designed for a homogenous group and oriented to the goal of the maintenance of the administration of justice on the most efficient and purest plane.

Now is a good time to recognize that the phrase "moral turpitude" grows out of a criminal law background. In applying it to the disbarment of attorneys it slould liave a new signiflcance in a new setting, or better still one may adopt a more suitable expression. If a lawyer commits a crime lie is entitled to no different treatment than any other criminal. But wlere the question is one of disbarment, a higher standard of conduct is expected than in the case of the average citizen.

The test of violation of the professional code is not to be expressed in terms of sin-a violation of man's duty to God; nor $\mathrm{m}$ terms of the criminal law because a lawyer may be pumished for his crimes independently of disciplinary proceedings. The seriousness of a violation of that standard should be expressed not primarily in terms of the moral code, nor the inherent quality of the act, but in the extent to whicl, in the minds of those competent to judge, the act has lowered the prestige of the legal profession and rendered less efficient the administration of justice.

In England disciplinary procedures are fundamentally professional. The General Council of the Bar aids in formulating a code of conduct. The benchers of the various Inns and a committee of the Law Society initiate disciplinary proceedings. The machimery works well there without the use of the term "moral turpitude." Conceivably some adaptation of it to the local needs in this country miglit be useful.

The remedy to be devised may well contain:

1. An agency for fornulating and keeping abreast of the times a professional code which is legally binding. The canons of ethics of the American Bar Association are not rules of law..$^{50}$ They might be made so by adoption as rules of court. ${ }^{51}$ In the State of Washington they have become statute law. ${ }^{52}$

49 Supra note 23.

50 Hunter v. Troup (1924) 315 Ill. 293, 146 N. E. 321; see In re Gray (1918)

184 App. Div. 822, 172 N. Y. Supp. 648.

61 In re Staton (1922) 112 Kan. 226, 210 Pac. 615.

02 Wash. Rev. Stat. ANN. (Remington, 1932) \$139-15; see ArIz. CodE (Struckmeyer, 1928) \$201. 
2. An agency for initiating disciplinary proceedings. The average present grievance committee is this agency in embryo.

The remedy unay now be suggested.

\section{A SUGGESTED REMEDY}

The following specific steps in each state are proposed, with due recognition of the difficulty of the task.

A. In place of the phrase "moral turpitude" to describe disbarable conduct substitute some other with the following characteristics:

1. It should be a term particularly applicable to professional standards as distimct from lay conduct.

2. It should be broad enough to imclude acts done by a lawyer in his private life or in other lines of work as well as unprofessional conduct.

3. It should be appropriate to a proceeding which is intended not for punishment but for the improvement of the administration of justice.

4. It should be flexible enough to meet the requirements of change and the exercise of discretion in administration, and should be relative to professional morals.

The term "conduct unbecoming an officer and a gentleman" had something of these four characteristics at least in a society where social distinctions were recognized. The term "conduct unbecoming a lawyer and a gentleman" is certainly no more indefinite than "conduct imvolving moral turpitude." The former tern is capable of definition, adaptation, and intelligent administration.

B. Establish an administrative machinery for the purpose of making a legally enforceable professional code and keeping it abreast of the times. This machinery would include the following:

1. The enactment of legislation relinquishing to the judicial department exclusive jurisdiction over the subject of disbarment.

2. Delegation by the court to the bar of a part of the responsibility as is the case with barristers in England.

3. The creation by the bar, where they do not now exist, and the official recognition of them by rule of court of two continuing committees. ${ }^{53}$

(a) One committee shall assume the task of formulating and constantly recreating a code of ethics.

53 With all due respect to the value of volunteer committees in voluntary bar associations, a perusal of the record of activity, for example, in disciplinary committees indicates that the more highly organized the bar the more active the committee will be. The Board of Governors of the California State Bar holds regular monthly meetings. For a summary of its work see monthly numbers of the StaTe Bar Jouratal. 
Such a code would include a list of offenses, violation of which should be followed by disbarment. It could be made more specific and detailed than the list of grounds now contamed in disbarment statutes. The practical results of such a compilation should compare favorably with those of any of the Restatements of the American Law Institute. It might be possible to enumerate with clarity all disbarable offenses. As to this group no "catch-all" phrase would be needed.

For acts warranting less serious disciplinary procedure such as suspension or censure, the phrase indicated above, "conduct unbecoining a lawyer and a gentleman," might suffice. In this field the discretion of the court might be allowed wide latitude in interpreting the circumstances of the case, because no exploratory expedition into extra-legal fields would be required to ascertain the state of the lay conscience. The committee should be a continuing one. New offenses will certainly arise requirmg the exercise of judgment as to whether they belong in the disbarable class or not. There will be constant change in the attitude of the profession and the public on such matters. The committee should be always on the alert to sense and evaluate such change, and if necessary revise the code.

(b) One committee shall assume the task of investigating and weighing the evidence, organizing and prosecuting the cases for disciplinary procedure-except such matters as arise in contempt cases where the court has the evidence before it.

There is nothing radical about either of these committees.

4. Lay representation on the two committees mentioned in the preceding paragraph. It is not enough to remove the hand ' of the legislature and place the matter entirely on a professional basis. The administration of justice, of which this disciplinary procedure is only a part, is a subject in which the public, as a matter of right, has an interest. $^{54}$ It is not a final answer to say that a standard of ethics peculiarly appropriate and acceptable to professional men must suffice. Two dangers lurk in such procedure. Professional groups having a monopoly and freed froin the goad of public criticism tend to decay. ${ }^{55}$ Public confidence in the profession is essential to continued success. It is customary to argue that the layman cannot understand the fine distinctions of the law, and that therefore he should be excluded. Whatever the theory, laymen as jurymen, commissioners in judicial and quasi-judicial tribunals, court officers, legislative commissioners

\footnotetext{
51 See Preamble to the Canons of Ethics of the American Bar Association (1934) 59 A. B. A. REP. 711.

55 For an interesting discussion of the various attempts to abolish the ancient Serjeants, see Pulling, Order of the CoIf (1897) p. 281 et seq.
} 
for the revision of law $w^{56}$ have not only contributed a valuable point of view to the administration of justice but have served to reassure the public. In one celebrated case ${ }^{57}$ it was found necessary to have a lay commission investigate the proceedings to convince the public that justice had been done. The consequences of popular distrust are so serious as to warrant unusual precautions by members of the profession.

There is nothing essentially novel in the suggestion of lay representation on committees to codify and administer legal etlics. The details of that representation are largely a local problem. A uniform system, ${ }^{58}$ no matter low carefully planned, would fail of general acceptance. So no effort is made here to consider the admimistrative machimery.

Lay representation will provide a blending of viewpoints. The layman's general code of morals is not adequate for the specialized needs of the bar. An exclusively professional code lacks the polish which comes froin a critical comparison of lay and professional standards of conduct. The lay concept of the lawyer's code as expressed by the legislature is inadequate and too restrictive. But a professional code modified in the making so as to allow for the lay viewpoint gives a sturdy but flexible answer to the dilemma.

5. The development of a national clearing louse $i m$ the American Bar Association where information as to disbarment and disciplinary proceedings may be collected from, and be made readily available to, all parts of the country. This wonld necessitate inaugurating the practice of publishing the results and opinions of all disciplinary proceedings. The collected materials would provide greater predictability and a scientific basis for future advance.

\section{CONCLUSION}

The following points have been made. One of the factors in the struggle between the legislative and judicial departments for control of the authority to promulgate standards for disbarment of attorneys is the use of the term "moral turpitude" to distinguish certain crimes for which disbarment is a proper punishment. The term does not have a definite meaning in spite of judicial efforts to clarify it. So far no one

56 (1929) 19 N. Y. Leg. Doc. No. 79; (1930) 1 N. Y. LEg. Doc. 4; N. Y. Laws, 1931 c. 186.

57 The Sacco-Vanzetti Case. See Emrarann, The Untrmed Case (1933) p. 231.

58 For example, if a proposal were made that the court appoint a committee of five, two to be laymen and the other three lawyers, discussion would develop, first, on the question of whether the court or the bar should appoint the committee; second, on whether five is a proper number, and third, on the question of whether the lay representation should be limited to one, two, or more. Obviously such matters are of local concern and no good purpose will be served by endeavoring to particularize them here. 
has found that fundamental factor which will distinguish between those acts which do and those that do not involve moral turpitude. The search appears to breed as much confusion as the original phrase. The suggested solution, then, is to abandon the effort to describe the morals of the legal profession in terms of lay codes, to establish and administer a professional code which shall cover both the professional and nonprofessional actions of the lawyer with due consideration given to the public interest im the subject. The profession cannot afford to allow the inevitable gulf between it and the general public to grow wider. Efforts to bridge it are always in order. To admit representatives of the general public to the councils of the profession is more than a courteous gesture. It is a step toward mutual understanding which will grow imto inutual tolerance, confidence, respect and harmony.

John S. Bradway.

ScHOOL OF Law, DURE UNIVERSITY. 